\title{
Biochemical markers and fertility rate of hydatid cyst isolated from human and animal in Sulaimani province
}

\author{
Abdullah Ahmed Hama \\ Medical Laboratory Dept. \\ Sulaimani Polytechnic University \\ MLS Dept. College of science Health, \\ Komar University of science and technology \\ Kurdistan-Iraq \\ Abdullah.hama@spu.edu.iq
}

\author{
Fatimah Mohammed Ali \\ Nursing Dept. \\ Slaimani Polytechnic University \\ Sulaimani, Iraq \\ fatema1972@yahoo.com
}

\author{
Kalil hassan \\ General Health Diarectirate of \\ Halabja \\ Halabja, Iraq \\ Khalik.hasan@yahoo.com
}

\author{
Wijdan M S. Mero \\ Biology Dept. \\ College of science \\ Zhako University \\ Zhako, Iraq
}

Wijdan2000@yahoo.com

\begin{abstract}
Hydatid disease is a helminthic infection, caused by the metacestode stage of cestode belonging to the Echinococcus grnulosus (dog tapeworm). The species and strain identification of Echinococcus are of medical importance for strategic control measuring. The present study achieved to determine and compare fertility and biochemical profiles of hydatid cyst fluid isolated from human, cattle, sheep and goat. The human originated cyst has been found to be more fertile (88\%), followed by sheep-originated cyst (85\%). The high rate of fertility was found in the liver followed by lungs in all intermediate hosts. However, the statistically significant differences of a biochemical test of cyst fluid among intermediate host were observed just in the uric acid, while the result of biochemical tests Hydatid cyst fluid isolated from liver significantly was higher than that of the lung for the most biochemical tests. The fertility and biochemical parameters value differences directly have related to the location of cyst and strains of $E$. granulosus. This finding concluded the sheep strain is a predominant strain and responsible for human and animal echinococcosis and sheep is the main intermediate host responsible for the perpetuation of the life cycle of $E$. granulosus in Sulaimani.
\end{abstract}

Keywords: Hydatid cyst, Echinococcus, Biochemical, Fertility, Strain, Cyst fluid.

\section{INTRODUCTION}

Echinococcus granulosus belong to class cestoda cause unilocular hydatid disease. There are four recognized species of Echinococcus, E. granulosus, E. multilocularis, E. oligarthrus and E. vogeli [1], [2]. The species of Echinococcus has a complex life cycle and they require two hosts to complete their life-cycle. The Metacestode (hydatid cyst) develops in the various organ of the intermediate host while the most common infected organ found to be liver and lung [3],[4].

Hydatid disease is also known as a silent zoonotic helminthic infection caused by the larval stages of Echinococcus granulosus, with global distribution [5]. Cystic echinococcus poses a significant economic and public health concern in Iraq and Kurdistan [6]. humans become infected by ingesting food or water contaminated with fecal material containing E. granulosus eggs passed from infected carnivores, or when they handle pet or infected dogs [1], [7], [8]. The larval stage (metacestode) can grow in various body organs, although the commonest sites of infection are the liver and lungs [9], whereas, the disease cannot be transmitted to humans or from human to dogs [10].

The new molecular tools is a most accurate method to determine genetic variation of E.granulosus to date ten distinct genotypes were identified (G1-G10) based on the DNA market [11], also morphological and biochemical criteria were studied by researchers [12],[13]. The strains of E.granulosus were found in the domestic animals known as intermediate hosts: sheep, pigs, cattle, horses, camels, goats and cervid [14], the researchers confirmed that seven of these strains were found to be infective to human [15]. The biochemical marker is reliable criteria for recognizing of E.granulosus strains variation [16]. The determining of the strains which are responsible for human infection is a significant point for long term strategically control plan of the hydatid disease. Morphological and Biochemical characterization of metacystode can be used for identification of strain variation in the endemic area [17]. Echinococcosis is constituted a major endemic disease in Iraq and Kurdistan Region with no long-term control plan, and its seriousness in humans and animals have been recognized by many epidemiological and biological studies [18], [19], [20]. Although there are no adequate studies of E. granulosis, this will open a new clue in strain identification and will be of great help in building effective control measures and predictive epidemiology, [21].

\section{MATERIALS AND METHODS}

The animal originated cyst was 19 hydatid cyst ( sheep $=10$, cattle $=6$ and goat $=3$ ) were collected from Sulaimani new abattoir and the human cysts (human=5) were collected from Scientific Hospital of Sulaimani after surgical operation, the protoscoleces and fluid were separated by centrifugation at $15000 \mathrm{rpm}$ at $4{ }^{\circ} \mathrm{C}$ for 10 minutes and the fluid was transferred to medical laboratory directly for biochemical test and the protoscolex were stored in $10 \%$ formalin $(\mathrm{v} / \mathrm{v})$ until microscopic examination for fertility [13].

The precipitate was examined by direct microscopy under (40x) for the presence of protoscoleces. The cysts which contain protoscoleces were considered as fertile [22].

Biochemical analysis: Glucose, urea, uric acid, 
triglycerides, cholesterol, G.P.T and G.O.T, were determined by the Enzymatic method, creatinine by Jaffe's method, and calcium by the O-kersolphthaleineKomplexon method. Serum total protein was estimated by Biuret method [23], Albumin was estimated by Bromo cresol green binding (BCG) method [24]. The biochemical test was estimated by a commercially available diagnostic kit from (Bio-Labo, France), the globulin concentration was calculated as the difference between the serum concentrations of total protein and albumin [25].

The data were analyzed by a statistical software program (SPSS version:17.0) and the mean was compared by one way ANOVA.

\section{RESULT}

The analysis of biochemical tests of hydatid cyst isolated from different intermediate host represented in the table (1). The mean of all biochemical test except uric acid among intermediate hosts has no statistically differences, while uric acid concentration in the cyst fluid isolated from cattle is significantly higher $(\mathrm{p}<0.05)$ than the other cyst fluid isolated from sheep, goat and human.

The table (2) shows a comparison of biochemical tests of cyst isolated from liver and lung of sheep to estimate the effect of cyst location on the metabolism of protoscoleces, the result shows the Alkaline phosphatase and triglyceride were significantly higher in the liver cyst than those of lung cyst.

The metabolism rate of the Hydatid cyst depending on the location (liver and Lung) were evaluated in the cattle(Table 3), the calcium, uric acid, bilirubin. Protein, Alkaline phosphatase and triglyceride were significantly higher in the liver cyst than those of lung cyst.

Figure (1) show the fertility rate of Hydatid cyst among sheep, goat, cattle and Human. The high fertility rate was found in human and sheep (88\% and 85\%) respectively, the fertility rate among goat and cattle were $60 \%$ for both host, while the sterile rate of the cyst was found to be very low in the sheep originated cyst.
Table 1. Biochemical test of hydatid cyst fluid isolated from intermediate host.

\begin{tabular}{|c|c|c|c|c|c|}
\hline \multirow{2}{*}{$\begin{array}{l}\text { Biochemical } \\
\text { test }\end{array}$} & \multirow{2}{*}{ unit } & \multicolumn{4}{|c|}{ Intermediate host } \\
\hline & & $\begin{array}{c}\text { Cattle } \\
\text { Mean+SE }\end{array}$ & $\begin{array}{c}\text { Goat } \\
\text { Mean+SE }\end{array}$ & $\begin{array}{c}\text { Sheep } \\
\text { Mean+SE }\end{array}$ & $\begin{array}{c}\text { Human } \\
\text { Mean+SE }\end{array}$ \\
\hline Glucose & $\mathrm{mg} / \mathrm{dl}$ & $50 \pm 6$ & $80 \pm 0.1$ & $49 \pm 9$ & $82 \pm 6$ \\
\hline Creatinine & $\mathrm{mg} / \mathrm{dl}$ & $1.1 \pm 0.2$ & $1 \pm 0.05$ & $1 \pm 0.1$ & $0.6 \pm 0.05$ \\
\hline Urea & $\mathrm{mg} / \mathrm{dl}$ & $48 \pm 5$ & $56 \pm 0.1$ & $53 \pm 4$ & $39 \pm 0.5$ \\
\hline Uric acid & $\mathrm{mg} / \mathrm{dl}$ & $2.1 \pm 0.4^{*}$ & $1 \pm 0.1$ & $0.7 \pm 0.1$ & $1.9 \pm 0.6$ \\
\hline Calcium & $\mathrm{mg} / \mathrm{dl}$ & $7 \pm 0.1$ & $3 \pm 0.1$ & $13 \pm 2$ & $11 \pm 4$ \\
\hline Bilirubin & $\mathrm{mg} / \mathrm{dl}$ & $0.1 \pm 0.001$ & $0.3 \pm 0.05$ & $0.3 \pm 0.08$ & $0.30 \pm 08$ \\
\hline $\begin{array}{c}\text { Alkaline } \\
\text { phosphatase }\end{array}$ & $\mathrm{U} / \mathrm{L}$ & $10 \pm 0.01$ & $50 \pm 0.5$ & $32 \pm 7.5$ & $13.3 \pm 0.8$ \\
\hline Globulin & $\mathrm{g} / \mathrm{dl}$ & $0.3 \pm 0.1$ & $0.5 \pm 0.01$ & $0.4 \pm 0.1$ & $0.5 \pm 0.01$ \\
\hline Cholesterol & $\mathrm{mg} / \mathrm{dl}$ & $3 \pm 1$ & $8 \pm 0.1$ & $6 \pm 2$ & $12 \pm 6$ \\
\hline Triglyceride & $\mathrm{mg} / \mathrm{dL}$ & $18 \pm 0.1$ & $40 \pm 20$ & $37 \pm 9$ & $39 \pm 2$ \\
\hline \begin{tabular}{|l} 
Total \\
protein
\end{tabular} & $\mathrm{g} / \mathrm{dl}$ & $0.6 \pm 0.1$ & $2 \pm 0.9$ & $1 \pm 0.2$ & $1 \pm 0.2$ \\
\hline \begin{tabular}{|l|} 
Total \\
Albumin \\
\end{tabular} & $\mathrm{g} / \mathrm{dl}$ & $0.2 \pm 0.01$ & $0.2 \pm 0.01$ & $0.4 \pm 0.1$ & $0.2 \pm 0.0$ \\
\hline S.G.O.T & $\mathrm{U} / \mathrm{L}$ & $2 \pm 0.1$ & $7 \pm 3$ & $8 \pm 1$ & $5 \pm 0.01$ \\
\hline S.G.P.T & $\mathrm{U} / \mathrm{L}$ & $7 \pm 0.1$ & $11 \pm 1$ & $6 \pm 1$ & $8 \pm 5$ \\
\hline
\end{tabular}

Table 2. Biochemical test of hydatid cyst fluid isolated from liver and lung of sheep

\begin{tabular}{|c|c|c|c|}
\hline \multirow{3}{*}{$\begin{array}{c}\text { Biochemical } \\
\text { test }\end{array}$} & \multirow{3}{*}{ Unit } & \multicolumn{2}{|c|}{ Intermediate host Sheep } \\
\hline & & liver & lung \\
\hline & & Mean \pm SE & Mean \pm SE \\
\hline Glucose & $\mathrm{mg} / \mathrm{dl}$ & $50.2 \pm 3.4$ & $50.3 \pm 5.5$ \\
\hline Urea & $\mathrm{mg} / \mathrm{dl}$ & $53.1 \pm 9$ & $52.5 \pm 5.3$ \\
\hline Creatinine & $\mathrm{mg} / \mathrm{dl}$ & $1.7 \pm 0.3$ & $1 \pm 0.2$ \\
\hline Uric acid & $\mathrm{mg} / \mathrm{dl}$ & $2.2 \pm 0.7$ & $0.8 \pm 0.4$ \\
\hline Cholesterol & $\mathrm{mg} / \mathrm{dl}$ & $6 \pm 2.9$ & $6.3 \pm 4.6$ \\
\hline Triglycerides & $\mathrm{mg} / \mathrm{dl}$ & $60 \pm 7 *$ & $14 \pm 2.2$ \\
\hline Calcium & $\mathrm{mg} / \mathrm{dl}$ & $13.1 \pm 3$ & $13.3 \pm 1$ \\
\hline Alk phosphatase & $\mathrm{U} / \mathrm{L}$ & $45.2 \pm 15^{*}$ & $16.8 \pm 1$ \\
\hline T. Protein & $\mathrm{g} / \mathrm{dl}$ & $1.4 \pm 0.4$ & $0.6 \pm 0.2$ \\
\hline Albumin & $\mathrm{g} / \mathrm{dl}$ & $0.55 \pm 0.2$ & $0.25 \pm 0.1$ \\
\hline Globulin & $\mathrm{g} / \mathrm{dl}$ & $0.54 \pm 0.2$ & $0.26 \pm 0.1$ \\
\hline T. bilirobin & $\mathrm{mg} / \mathrm{dl}$ & $0.33 \pm 0.1$ & $0.27 \pm 0.06$ \\
\hline S.G.P.T & $\mathrm{U} / \mathrm{L}$ & $6.8 \pm 1.2$ & $5.2 \pm 0.2$ \\
\hline S.G.O.T. & $\mathrm{U} / \mathrm{L}$ & $12.3 \pm 6.2$ & $4.2 \pm 0.4$ \\
\hline
\end{tabular}


Table 3. Biochemical tests of the hydatid cyst isolated from liver and lung of cattle.

\begin{tabular}{|c|c|c|c|}
\hline \multirow{3}{*}{$\begin{array}{c}\text { Biochemical } \\
\text { test }\end{array}$} & \multirow{3}{*}{ Unit } & \multicolumn{2}{|c|}{ Intermediate host cattle } \\
\hline & & liver & lung \\
\hline & & Mean \pm SE & Mean \pm SE \\
\hline Glucose & $\mathrm{mg} / \mathrm{dl}$ & $54.6 \pm 6$ & $45.4 \pm 0.3$ \\
\hline Urea & $\mathrm{mg} / \mathrm{dl}$ & $47.2 \pm 3.1 *$ & $49 \pm 0.1$ \\
\hline Creatinine & $\mathrm{mg} / \mathrm{dl}$ & $1.5 \pm 0.4$ & $1.4 \pm 0.8$ \\
\hline Uric acid & $\mathrm{mg} / \mathrm{dl}$ & $1.9 \pm 2$ & $2.4 \pm 0.6$ \\
\hline Cholesterol & $\mathrm{mg} / \mathrm{dl}$ & $3.7 \pm 7 *$ & $0.45 \pm 0.3$ \\
\hline Triglyceride & $\mathrm{mg} / \mathrm{dl}$ & $7.1 \pm 10^{*}$ & $3.65 \pm 4.9$ \\
\hline Calcium & $\mathrm{mg} / \mathrm{dl}$ & $4.3 \pm 0.01^{*}$ & $9.7 \pm 0.1$ \\
\hline $\begin{array}{c}\text { Alk. } \\
\text { phosphatase }\end{array}$ & $\mathrm{U} / \mathrm{L}$ & $10.7 \pm 15^{*}$ & $9.3 \pm 1$ \\
\hline T.Protein & $\mathrm{g} / \mathrm{dl}$ & $0.9 \pm 0.1^{*}$ & $0.3 \pm 0.01$ \\
\hline Albumin & $\mathrm{g} / \mathrm{dl}$ & $0.1 \pm 0.03$ & $0.4 \pm 0.1$ \\
\hline Globulin & $\mathrm{g} / \mathrm{dl}$ & $0.35 \pm 0.1$ & $0.25 \pm 0.08$ \\
\hline T.bilirobin & $\mathrm{mg} / \mathrm{dl}$ & $0.01 \pm 0.1 *$ & $0.65 \pm 0.05$ \\
\hline G.P.T & $\mathrm{U} / \mathrm{L}$ & $8.2 \pm 1.2$ & $5.8 \pm 0.2$ \\
\hline G.O.T. & $\mathrm{U} / \mathrm{L}$ & $1.3 \pm 6.2$ & $2.7 \pm 0.4$ \\
\hline
\end{tabular}

*indicate significant differences $(\mathrm{p}<0.05)$

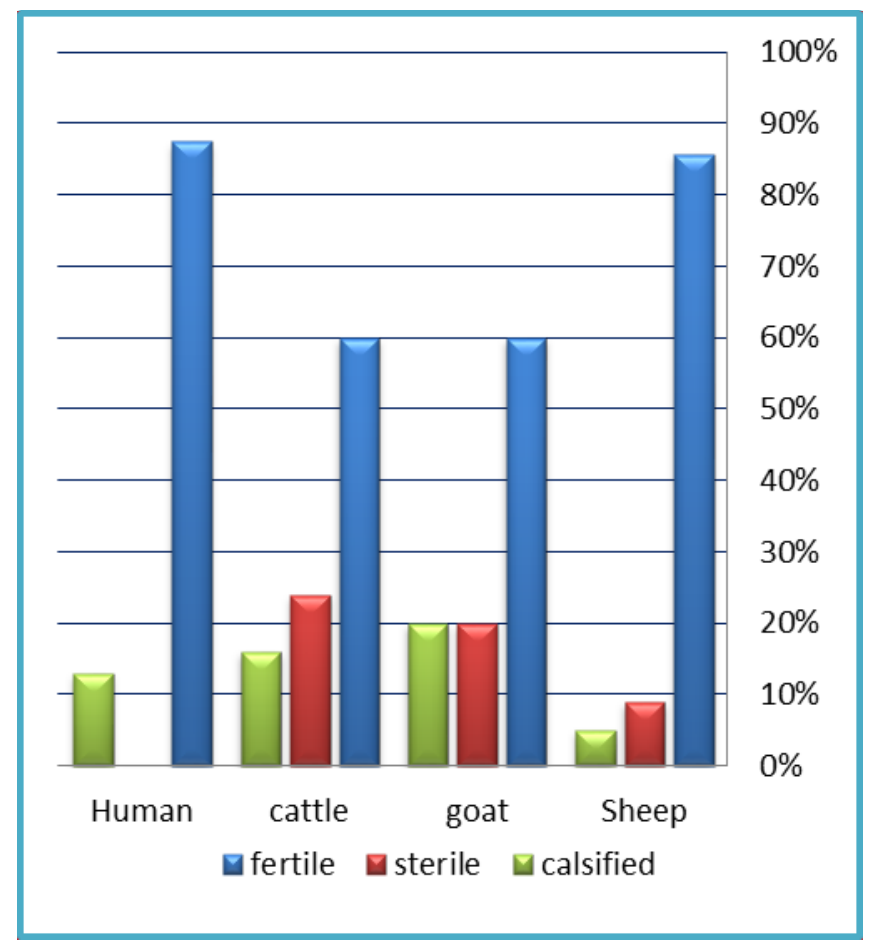

Figure 1. Fertility rate of Hydatid cyst isolated from sheep, goat, cattle and Human.

\section{DISCUSSION}

The metabolism rate of hydatid cyst can be determined by a biochemical test which plays an essential role in growth rate and control of the cystic echinococcosis [26]. The biochemical tests can be used as biochemical markers for determining the species and strain of Echinococcus. The variation in the metabolism rate and biochemical tests of hydatid cyst may reflect strain variation in different intermediate hosts [2], [27].

In the present study, the author used biochemical tests of hydatid cyst fluids isolated from sheep, goats, cattle and humans as a biochemical marker to determine the strain variation of Echinococcus granulosus, also the fertility of the hydatid cyst determined which has directly related to the host and infected organ [5].

The concentration of uric acid was found to be significantly higher in human and cattle cyst fluid compared with other cyst fluids, in the similar studies in Iran Radfar and Iranyar [28] and Shaafie et al. [26]support our finding, they record higher concentration of uric acid in human originated cyst and they state this high concentration of uric acid may due to normally high concentration of uric acid in the human and cattle.

The level of glucose and cholesterol were found to be higher in the cyst fluids of goat and human, compared with sheep and cattle, indicating that the concentration of these parameters are not affected by the hosts, and the other this finding agrees with Radfar and Iranyar [ 28] and Shaafie et al. [29] they demonstrated no marked quantitative differences in protein, total lipid, phospholipids, cholesterol and glycerides in hydatid cyst fluids collected from cysts obtained from intermediate host.

In the present study, the biochemical similarities of hydatid cyst fluids from sheep, goats, and humans, and variation in the biochemical tests of hydatid cyst fluids of cattle from other intermediate hosts, suggest the existence of different strain of Echinococcus granulosus in Kurdistan-Iraq this result agree with [4], [6] and [30] they record sheep and cattle strain using molecular markers in Kurdistan Iraq. .

The molecular DNA marker and Morphological marker were studies of E. granulosus in Kurdistan-Iraq and report the existence of two distinct strains of $E$. granulosus in Kurdistan-Iraq, with the sheep strain occurring in sheep, cattle and humans and the cattle strain occurring in cattle [17], [30].

The sheep strain is the common strain which is responsible for human infection [5], [2].

The good strategical control plan need entire information about intermediate host and strain of Echinococcus in the endemic area, the most common intermediate host in the Middle East are sheep, camel, cattle, goats and horse [31], [5] and [30], many studies indicated the protoscoleces content (viability) has directly related to the biochemical test value [31]. The location of cyst also influence on the biochemical profile of the cyst fluid, our finding shows the liver concentration of the most biochemical parameters are higher than the cyst fluid isolated from the lung in both sheep and cattle, this result supported by Refik et al. [32]. 
The fertility rate of Hydatid cyst were higher in the cyst isolated from human followed by sheep it is an indicator that sheep strain can grow properly and act within his suitable host (sheep) and the infected organ also play major role in the fertility of the cyst, the majority of the liver cyst were fertile [32]. The majority of the human originated hydatid cyst was fertile $(88 \%)$ just about $12 \%$ were calcified the sterile cyst was not found in a human this result may due to the location of the cysts all human cyst were taken from the liver which is a suitable environment for hydatid cyst [4].

\section{References:}

[1] J. Eckert, A. M. Gemmell, F. X. Meslin, and Z. Pawlowski, "WHO / OIE manual on Echinococcosis in humans and animals: a public health problem of global concern", Paris: Office International des., Epizooties. pp. 225, 2002.

[2] R. C. A. Thompson, "Biology and systematics of Echinococcus. In Echinococcus and hydatid disease", In: (Thompson, R. C. A. and Lymbery, A. J. (1995). CAB Int. Wallingford, pp.50, 1995.

[3] S. Khademvatan, E. Yousefi, A. Rafiei, M. Rahdar, and J. Saki," Molecular characterization of livestock and human isolates of from south-west Iran", J Helminth. vol. 87, pp. 240-244. 2013.

[4] A. A. Hama, "Epidemiological study and Molecular characterization of E. granulosus, in KurdistanIraq", $\mathrm{PhD}$. Thesis, College of Science, University of Zakho, 2013.

[5] W. M. S. Mero, J. M. S. Jubrael, and A.A. Hama, "Prevalence of hydatid disease among slaughtered animals in Slemani Province/Kurdistan-Iraq", J. UOZ 2, pp. 33-38, 2014.

[6] A.A. Hama, W.M.S. Mero, and J.M.S. Jubrael, "Molecular characterization of E. granulosus, first report of sheep strain in Kurdistan-Iraq" , 2nd International Conference on Ecological, Environmental and Biological Sciences (EEBS ${ }^{\mathrm{TM}}$ 2012). Oct. 13-14, Bali, Indonesia., 2012.

[7] WHO, "The control of neglected zoonotic diseases", meeting with the participation of FAO and OIE. Geneva., 2006.

[8] A. R. Satoskar, G. L. Simon, P.J. Hotez, and M. Tsuji, "Medical Parasitology, Landes Bioscience, Texas", pp.320, 2009.

[9] E. K. Markell, D.T. John, and W.A. Krotoski, "Medical Parasitology" 8th ed. W. B. Saunder Company. pp. 253-261, 1999.

[10] K.A. Rood, and J. Kelly, "Prevention of Hydatid Disease", Anim. Health., vol.1,pp. 1-7, 2009.

[11] L. Rinaldi, M.P. Maurelli, F. Capuano, A. G. Perugini, V. Veneziano, and S. Cringoli, "Molecular update and cystic echinococcosis in cattle and water Buffaloes of southern Italy", J. Blackwell Verlag. Zoonosis, public. Health., vol. 55, pp.119-123, 2008.
[12] L.M. Kumaratilake, and R. C. A. Thompson, "A comparison of Echinococcus granulosus from different geographical areas of Australia using secondary cyst development in mice", Int. J. Parasitol., vol.13, pp.509-515, 1983.

[13] A. A. Latif, A. Tanveer, A. Maqbool, N. Siddiqi, M. Kyaw-Tanner, and R. J. Traub, "Morphological and molecular characterization of Echinococcus granulosus in livestock and humans in Punjab, Pakistan", J. Vet. Parasitol., vol.170, pp. 44-49, 2010.

[14] E. Sanchez, O. Caceres, C. Naquira, D. Garcia, G. Patino, H. Silvia, A. C. Volotao, and O .Fernandes, "Molecular characterization of Echinococcus granulosus from Peru by sequencing of the mitochondrial cytochrome oxidase subunit 1 gene", Res. Dev. J., 105(6), pp. 806-810, 2010.

[15] J. Eckert, M.A. Gemmell, F. X. Meslin, and Z. S. Pawlowski, In: "WHO/OIE Manual on Echinococcosis in Humans and Animals: A Public Health Problem of Global Concern" Paris OIE. pp. 1-265, 2001.

[16] M.F. Harandi, R.P. Hobbs, P.J. Adams, I. Mobedi, U. M. Morgan-Ryan, and R.C.A. Thompson, "Molecular and morphological characterization of Echinococcus granulosus of human and animal origin in Iran." J.Parasitol., 125, pp. 367-373. (2002).

[17] A.A. Hama, et al.," A morphologically unusual Echinococcus granulosus (G1 genotype) cyst in a cow from Kurdistan - Iraq" Special Issue: Clinical epidemiology., 5(Special Issue 2), pp.S2-5, 2015.

[18] N. Magid, Prevalence of hydatid cyst among slaughter animal in Duhok province, M.Sc. Thesis, College of Veterinary Medicine, Univ. of Duhok. (2008).

[19] A. A. Hama and O. H. Shareef, "Morphological and morphometric study of Echinococcus granulosus ( metacestode) in Sulaimani Province / Kurdistan", vol. 1, no. 1, pp. 1-6, 2016.

[20] A. M. Abdullah, "Epidemiological, Comparative Enzymatic and Total Protein content of hydatid cyst of Ecchinococcus granulosus isolated from Sheep and Goats in Duhok province, Kurdistan Region of Iraq", M.Sc. Thesis, College of Education, Univ.of Duhok, 2010.

[21] H. R. Rahimi, E. B. Kia, S. H. Mirhendi, A. Talebi, H.M. Fasihi, N. Jalali-zand, and M. F. Rokni, " A new primer pair in ITS1 region for molecular studies on Echinococcus granulosus", J. Public, Health., 36 pp. 45-49, 2007.

[22] A. Daryani, R. Alaei, R. Arab, M. Sharif, M. H. Deghahan, and H. Ziaei, "Prevalence of hydatid cyst in slaughtered animals in northwest Iran", J. Anim. and Vet. Adv., vol, 5, no. 4 pp. 330-334, 2006.

[23] B. D. Ahmed, "Molecular Characterization of Echinococcus granulosus Cysts Isolated From 
Human and Animal Intermediate Hosts in Duhok Province, Kurdistan Region, Iraq", PhD. Thesis, College of Medicine, Univ. of Duhok, Kurdistan Region, Iraq, 2012.

[24] T. Ueno, S. Hirayama, M. Ito, E. Nishioka, Y. Fukushima, T. Satoh, M. Idei, Y. Horiuchi, H. Shoji, H. Ohmura, T. Shimizu, and T. Miida, "Albumin concentration determined by the modified bromocresol purpl method is superior to that by the bromocresol green method for assessing nutritional status in malnourished patients with inflammation", Journal Annals of Clinical Biochemistry, vol. 50 no.6, pp.576-584, 2013.

[25] M. Fulks, R. L. Stout, and V. F. Dolan, '"Serum globulin predicts all-cause mortality for life insurance applicants", Journal of Insurance Medicine, vol. 44, pp.93-98, 2014.

[26] I .A. Shaafie, A. H. Khan, and K. Rambabu, "Biochemical profiles of hydatid cyst fluids of $E$. granulosus of human and animal origin in Libya", J. Helminthol. vol.73, pp. 253-258, 1999:

[27] D. P. Mcmanus, and C. N. L. Macpherson, "Strain characterization in the Hydatid organism, Echinococcus granulosus. Current status and new perspective", Ann. Trop. Med. Parasitol. vol. 78, pp. 193-198, 1984.

[28] M. H. Radfar, and N. Iranyar," Biochemical profiles of hydatid cyst fluids of Echinococcus granulosus of human and animal origin in Iran Vet. Arhiv., vol. 74, pp. 435-442, 2004.

[29] Z. I. Hassan, A. A. Meerkhan, B. Boufana, A. A. Hama, B. D. Ahmed, W. M. S. Mero, S. Orsten, M. Interisano, E. Pozio, and A. Casulli, "Two haplotype clusters of Echinococcus granulosus sensu stricto in northern Iraq (Kurdistan region) support the hypothesis of a parasite cradle in the Middle East", Acta Trop., vol. 172, no. April, pp. 201-207, 2017.

[30] S. Kamhawi, , and N. Hijjawi, "Current studies on the epidemiology of unilocular hydatidosis in Jordan and its social implication", Report on Parasitic Diseases of the Middle East. National Institutes of Health, Bethesda, Maryland, pp. 8. 1992.

[31] M. Kouidri, F. B. Khoudja, A. Boulkaboul and S. A. Selles "Comparative Study on Fertility, Viability and Biochemical Profiles of Hydatid Cyst Fluid from the Lungs and Liver of Sheep in Algeria", World Applied Sciences Journal 31 vol.10, pp. 1699-1703, 2014.

[32] M. Refik, N. Mehmet, B. Durmaz, and M. Eğri, " Determination of some biochemical parameters in hydatid cyst fluids", Erciyes Tip Derg., vol. 24, no. 1, pp. 10-13, 2002.

\section{CONFLICT OF INTEREST:}

The authors declare that there is no conflict of interests.

\section{ACKNOWLEDGMENTS}

The authors wish to thank the Health Directorate of Halabja and Sulaimani scientific hospital for his kind support and facility. 